\title{
The Impact of Tariff Reduction on Poverty in Zimbabwe: A CGE TOP-Down APPROACH ${ }^{1}$
}

\author{
Margaret Chitiga \\ Department of Economics, University of Pretoria \\ Ramos Mabugu \\ Department of Agricultural Economics, University of Pretoria
}

\begin{abstract}
This paper uses a relatively new approach to quantify the effects of trade liberalisation on poverty. It relies on the combination of a standard, social accounting, matrix-based, computable general equilibrium model and household micro-data. These two tools are used sequentially in order to simulate the impact of trade policy reform. This framework enables the decomposition of the effects of trade liberalisation, which in turn allows for an analysis of alternative social policy packages. The methodology is applied to Zimbabwe for illustration. The results show that poverty is reduced by tariff reduction, although the poor households get the least benefits.
\end{abstract}

JELC68; H27; I32

1

\section{Introduction}

In the late 1990s, interest flourished in the area of trade policy effects on poverty and income distribution in a general equilibrium framework (Boccanfusso et al., 2002). Trade policies have important effects on income distribution and poverty since they have the potential to lead to substantial changes in resource allocation. These concerns have prompted most of the studies in this area to use computable general equilibrium (CGE) models to analyse the effects of trade policy. Such analyses now form an important part of routine overall policy assessments. However, attempts to include poverty explicitly into CGE model formulations are scarce (Savard, 2003). This paper seeks to add to efforts aimed at analysing the impacts of trade policy on poverty using a CGE model and a household survey database. The approach developed is applied to the case of Zimbabwe, where such analysis has not been attempted before.

There are already several CGE models addressing trade policy impacts for Zimbabwe (see for example Davies, Rattsø \& Torvik 1994, 1998; Bautista, Lofgren \& Thomas, 1998; Mehlum, 1999; Chitiga-Mabugu, 2001; and Mabugu, 2001). All these studies emphasise the effects of trade policies on the economy without directly connecting trade and external policies to poverty within the same framework. If a link is made between these issues it is often indirect. This paper builds on this earlier work and makes a contribution by developing a formal link between trade policy and poverty and then applying this approach to Zimbabwe. The approach taken for this analysis is what is known as a top-down CGE approach, in the sense that simulation changes from the CGE model are applied to household data and then poverty is analysed. This approach is in the same family of approaches such as the bottom-up CGE approach, which utilises results from the micro-data in the CGE model, and the integrated CGE approach, in which the CGE model is run with all the household survey households (see Savard, 2003).

The paper starts in Section 2 by discussing some key characteristics of Zimbabwe that are important for the analysis. Section 3 then 
presents the model and assumptions that lie behind the analysis. Section 4 reports and explains the results. Finally, section 5 draws general conclusions from the study and suggests some areas for future research.

\section{2}

\section{Background}

Trade and external policies have been central to Zimbabwe's development strategy since independence. A number of sources give a comprehensive documentation of trade policy in the 1980s (see for example Elbadawi \& Schmidt-Hebbel, 1991; Pakkiri \& Moyo, 1986). During this period, tariffs were used mainly as an instrument to raise revenue with the role of protection of industry being assigned to import and exchange controls. Pressure on the balance of payments led government to turn to tariffs in an attempt to reduce surging import demand. In 1983, Zimbabwe adopted the Customs Cooperation Council Nomenclature, which increased the number of headings which had to be allocated duty rates from 331 items to over 5000. Some problems of inconsistencies were encountered due to this move. In 1988, the move to Harmonised Commodity Description and Coding System, with over 7000 headings, worsened the problem. Duty rates were raised in this year in order to meet the increased demand for revenue from the government.

By the end of the 1980s, the tight system of controls had become progressively difficult to administer and largely ineffective. Pressure from the Bretton Woods institution to open up trade was also increasing at that time. These reasons, together with the general stagnation of the economy and increasing unemployment led to a decision by the government to adopt a World Bank/International Monetary Fund (IMF) supported economic structural adjustment program (ESAP) in 1991. A major component of ESAP was trade liberalisation. The measures taken to liberalise trade were varied and included the gradual phasing out of foreign currency rationing through the introduction of an Open General Import Licence (OGIL). Firms were allowed to retain some of their foreign currency earnings while the Zimbabwean dollar was devalued several times. Foreign currency bureaux were allowed to operate for the first time since independence.

Between the implementation of ESAP and 1996, there were frequent amendments to the tariff structure and it became obvious that a major revision was required. An average tariff of 16 per cent plus a surcharge of 15 per cent on most goods was applied to imports during this period. In 1997, a new tariff structure was launched. Tariffs on raw materials and partly processed inputs were substantially reduced to reduce investment costs. The removal of customs duty on capital goods was seen as a way of reducing production costs and thus increasing competitiveness (Reserve Bank of Zimbabwe, 1997: 20). Table 1 below gives the old and new tariff rates for 1997.

Table 1

Structure of tariff rates

\begin{tabular}{|l|c|c|}
\hline Goods & Previous rates of duty (\%) & New rates of duty (\%) (1997) \\
\hline Raw materials & $0-40$ & 5 \\
Merit goods: & & 5 \\
$\quad$-Education & $0-40$ & $0-20$ \\
$\quad$-Medical & $0-20$ & 0 \\
$\quad$-Goods for the blind & $0-10$ & 0 \\
Capital goods & $0-25$ & $5-15$ \\
Tools & $0-20$ & 15 \\
Spares & $0-56$ & 15 \\
Partly Processed Inputs & $0-55$ & $20-30$ \\
Intermediate goods & $0-35$ & \\
and consumables & & $40-85$ \\
Finished goods & $0-85$ & \\
\hline
\end{tabular}


The expected positive effects of trade liberalisation had not fully materialised by the end of the reforms. During the period 19912001, the rate of real GDP growth (adjusted for inflation) showed a sharp decline in 1992 during the drought, a gradual recovery through 1994, followed by a fall in 1995 and further recovery in 1996 and then sustained declines to the end of 2001 (Figure 1). Real GDP fell by an average of more than 6 per cent in 2000/01 and by more than 30 per cent in 2002/03. Inflationary pressures worsened in 2003 and further reduced the competitiveness of exports. The economy continued to suffer from continued uncertainty over the land reform programme, declining productivity on resettled farms and shortages of foreign exchange. Agriculture and manufacturing were the worst affected in 2002 and 2003.

Figure 1

Annual percentage change in real GDP, Zimbabwe 1991-2001

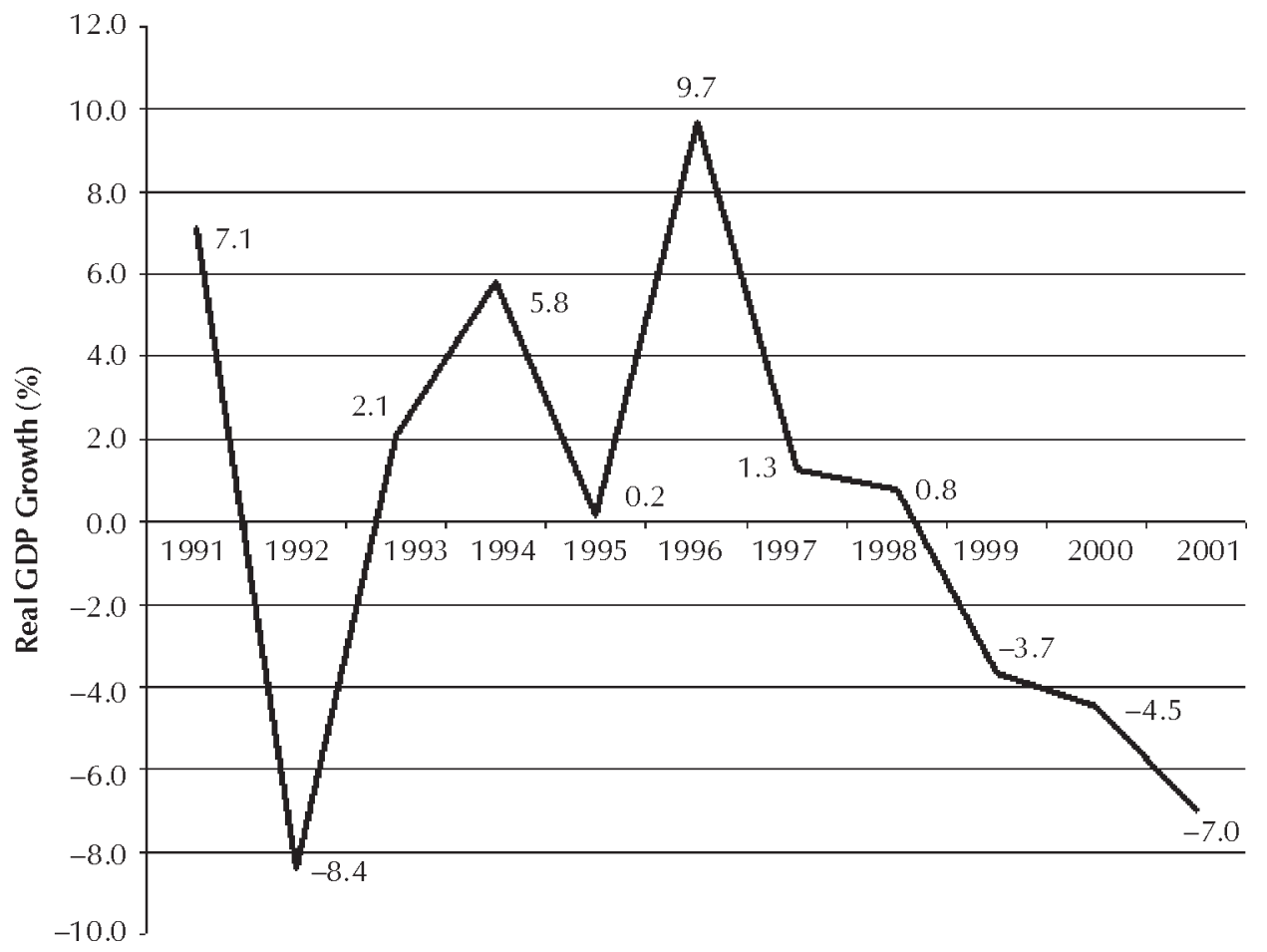

Source: RBZ, 2001, RBZ, 2002a, RBZ, 2002b.

It appears that the reforms may have stimulated export growth. In the period before adjustment, (1981-90) the US\$ value of exports grew by 2.4 per cent per annum and fell to -2.6 per cent during the first phases of adjustment. However, between 1994 and 1998, export growth averaged 5 per cent per year. Zimbabwe's external position has deteriorated substantially since 2000, largely as a result of the impact of the foreign aid freeze and declining exports. The declining exports caused a dramatic foreign currency shortage, which in turn reduced imports. High inflation, against an overvalued fixed exchange rate, harmed competitiveness and exports in 2002 were 36 per cent down on 2000. Exports in 2003 are estimated at half the 1996 figure. The trade deficit widened from 2.4 per cent of GDP in 2001 to an estimated 15.6 per cent in 2003 (OECD, 2004). The trade deficit is projected to widen in 2004, as exports, especially of tobacco and gold, are expected to fall more rapidly than imports. The negative 
developments on the current account and the deterioration of the capital account since 2000 have exacerbated the foreign currency crisis.

There is general agreement that poverty has increased in the nineties, ever since the onset of the reform programme (World Bank, 1998). Poverty is likely to have worsened since 2000, owing to the economic crisis, strained relations with donor groups, the impact of the land reform and the severe drought. Reports are that 5.5 million people out of the population of approximately 12 million were facing starvation in 2004. The Central Statistical Office (CSO)'s Income, Consumption and Expenditure Survey (ICES) of 1990-91 and 1995-96 are some of the major sources of most estimates on poverty and income inequalities. On the basis of this data, the World Bank (1998) estimated that 25 per cent of the population of Zimbabwe was poor and seven per cent was very poor. The results from the 1995 Poverty Assessment Survey Study, (PASS), gave higher figures than the World Bank. The PASS survey found that poverty is more prevalent in rural areas, with a total of 75 per cent of households in the poor category compared to 39 per cent in the urban areas. Communal areas have the highest incidence of poverty ( 84 per cent of households), followed by the resettlement areas and small-scale commercial farms (70 per cent), large-scale commercial farms (57 per cent) and urban areas (39 per cent), (PASS, 1996). The general trend is that the rural areas are much poorer than the urban areas. In general, most studies find that rural poverty, the main phenomenon in Zimbabwe, is most acute among smallholders in the communal areas. The question of interest for this paper is how far tariff policies influenced income distribution and, in particular, poverty in Zimbabwe, following the trade liberalisation measures adopted. This will assist in answering the question about how far such trade policies can be used in future to try and influence the allocation of resources between various groups and sectors of the economy with a view to reducing poverty.

\section{3}

The model

\subsection{Modelling the general economy}

The CGE model used allows us to simulate the effects of trade policies on income distribution and poverty in Zimbabwe. The structure of the model is based on the economy of Zimbabwe. The data used is presented as a Social Accounting Matrix (SAM) for Zimbabwe for 1995 (Chitiga et al., 2000). The model used is based on the International Food Policy Research Institute (IFPRI) standard model developed by Lofgren et al. (2001), from which the mathematical form of the model can be obtained. The aggregated SAM contains the following sectors and commodities; Food Agriculture (FA), Other Agriculture (OA), Food Manufacturing (FM), Agricultural Input Manufacturing (AIM), Other Manufacturing and Mining (OMM), Construction ( $\mathrm{CON})$, Public Services (PUS) and Private Services (PRS). In addition, the SAM is disaggregated into factors of production and institutions.

The production side is described by nested production functions as depicted in Figure 2. The activities accounts produce goods and thus represent the producers. They are assumed to maximise profit subject to given production functions. Thus they hire factors until marginal revenue for each factor equals factor prices. The model incorporates four labour types, distinguished as skilled labour, agricultural unskilled labour, formal non-agriculture unskilled labour and informal non-agriculture unskilled labour. Capital is employed in all the sectors and is distinguished as smallholder agricultural capital, large-scale agricultural capital and non-agricultural capital. In the agricultural sectors, land is also identified as a factor of production. As in the case of capital, land is also split into smallholder agricultural land and large-scale agricultural land. Production of output (X) is modelled as multilevel Constant Elasticity of Substitution (CES) and Leontief functions (Lofgren et al., 2001). Commodities are produced from activities by fixed-yield coefficients. The activities employ value-added and intermediates in a Leontief 
fashion. Value-added is a CES combination of primary commodities made up of labour, capital and land. Intermediates are a Leontief function of the composite commodity, which is made up of domestic and imported commodities. Once the choice of the factors is made, producers combine these with intermediates in a Leontief function.

\section{Figure 2}

Description of the production technology nesting

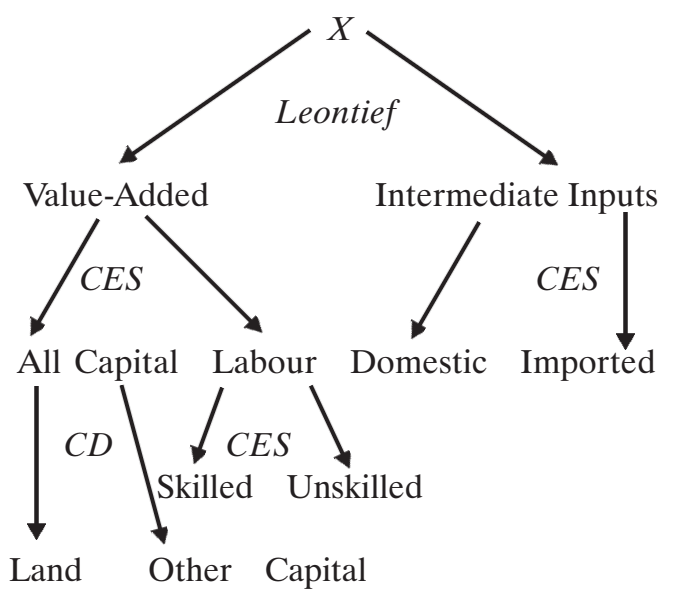

Primary factors have different closures. Land is used only in the agricultural sector, and both land and capital are fixed in the short term. There are different labour types with different closures associated with each. Unskilled labour in the rural areas is labour employed on largescale commercial farms. Unskilled labour is assumed to be in excess supply but immobile between rural and urban areas in the short term. However, it is mobile within sectors in either rural or urban areas.

The closure for skilled labour is that it is assumed to be in short supply and thus full employment of this labour type prevails. Its nominal wage is left as the adjusting factor between supply and demand. Capital is differentiated between rural and urban capital and fixed in each sector so that its price is the variable used to equilibrate the capital market. Land between smallholder and large-scale farm land is assumed different and thus sector specific. The allocation of land in each sector is according to its marginal value-added.

The model makes the usual Armington (1969) assumption of imperfect substitutability between the domestic commodities and imports. Thus people demand a composite good, which is a CES aggregation of imports and domestically produced goods. The decision to export or to sell domestically is determined on the assumption that domestic producers maximise profits subject to imperfect transformability between these two types of goods. The composite good is a constant elasticity of transformation (CET) aggregation of exports and domestically consumed goods. These assumptions of imperfect substitutability and transformability allow for the domestic price to have some degree of autonomy from international prices and thus allows for a reduction in export and import responses to the changes in the producer environment. This allows for two-way trade at the sectoral level, which reflects what is observed empirically in many countries (Lofgren et al., 2001).

Institutions consist of households, government, enterprises and the rest of the world. There are five types of household groups, as follows: communal and resettled farmers' households (HCR), low-income agricultural wage workers' households (HLILS), highincome agriculture managers and large farm owners' households (HHLS), low-income urban households (HLS) and high-income urban skilled households (HHU). Households can receive income transfers from the government, other households and the rest of the world. They can also receive factor income from factors of production directly or indirectly through enterprises. The income is spent on payment of taxes, savings, sectoral commodity consumption and transfers to other institutions. The average propensity to save is assumed flexible for households while there are fixed shares of direct taxes and transfers to other institutions from income. Consumption demand is specified as a linear expenditure system where we allow for a minimum subsistence level of consumption for each commodity. Enterprises receive income from certain factors, and transfers from other institutions. They pay taxes, 
save and transfer income to other institutions but do not consume.

The government receives taxes from institutions, commodities and activities. These taxes are given as fixed ad valorem rates. Data from the SAM used for 1995 shows that the government received 46 per cent of its total income from direct taxes (income, corporate and profits taxes), 25 per cent in the form of indirect taxes (taxes on goods and services), 19 per cent from import tariffs (import duties, exchange taxes etc), and the remainder (10 per cent) came from the rest of the world (ROW) as transfers. Government expenditure is on commodities and on transfers to other institutions. The government's consumption is fixed in real terms and transfers are indexed to the consumer price index. Government savings are left as the flexible balancing item. Transfers to and from the rest of the world are fixed in foreign currency terms as in Lofgren et al. (2001). Foreign savings are the difference between what is spent and what is received in foreign currency terms. All savings from all institutions are then used to finance investment.

Equilibrium in a CGE model is defined by a set of constraints that need to be satisfied by the economic system. In addition to the supplydemand balances in the product and factor markets, there are three other macro-economic balances specified in the model. These are the fiscal balance (where government savings equals the difference between government revenue and spending), the external trade balance (which implicitly equates the supply and demand for foreign exchange) and the savings-investment balance (see Lofgren et al., 2001). The model is square in the sense that the number of equations is equal to the number of variables. It is solved as a system of simultaneous non-linear equations. The model is a Walrasian economy that solves for relative prices. The numeraire of the model is the producer price index.

\subsection{Modelling poverty in a CGE framework}

The common way of analysing income distribution using CGEs, when the data set is a SAM, is to implicitly assume that there is no variance of income within a given household group because intra-group income distribution is not considered. This type of analysis assumes that the households within a given group are the same and can be represented by a representative household. This is often not the case as within group variations and across group variations are of the essence. Further, the characteristics of each group can be so different that they make a difference in terms of responses to policies. For poverty issues, these differences occur and should be taken into account. This suggests that we must take into account intragroup distributions which allow for an in-depth analysis of poverty. In this case, the distribution of poverty within each group is considered before considering the collection of groups together.

Attempts to include poverty explicitly in the model formulation are rare. This study is one of the few studies that makes such an attempt. The common forms used in most studies are to assume a certain form of distribution of income for the country and then use this form to construct poverty measures for the model. For example, Adelman and Robinson (1979) used a $\log$ normal distribution while Stifel and Thorbecke (1999) used the Beta function for an archetype African economy to study the poverty implications of policies and shocks. Boccanfuso et al (2002) compare several forms of distribution and comment on the impacts of each choice on the results. These assumed distributions are necessary in the case where a household survey is not available.

When a household survey is available, there is no need to determine $a$ priori the distributional function form. This data can instead be used directly to determine the underlying distribution for each of the socio-economic groups. This is the approach taken in this paper. More specifically, we use a top-down approach as opposed to an integrated approach or a bottom-up approach. The changes in income that occur after a simulation for each group as represented in the Macro model are used to change each household's income, and then poverty analysis is carried out using the household survey. This is why this approach is known as the top-down approach. Furthermore, 
because the prices of commodities are endogenous in the CGE model, an updating of an exogenous national poverty line is possible. The basket of goods that forms the national poverty line does not change in the short term as policy changes. The prices for the respective commodities in the basket change as policy changes, and so the monetary poverty line also changes. This formulation ensures that the poverty line is endogenous, as commodity prices will be endogenously determined within the model (Decaluwé et al., 1999). Such a model can now produce results of changes in the poverty line due to a policy change.

Using the Foster, Greer and Thorbecke (FGT) (1984) measures, we can further understand poverty. With different values of alpha we are able to tell how severe and intense the poverty is (see Ravaillon, 1994, and Decaluwé et al, 1999). The FGT measures are used to decompose poverty into the population below the poverty line (poverty headcount), the depth of poverty and the severity of poverty. For a continuous case the FGT index is defined as:

$\mathrm{P}_{\alpha}=\int_{0}^{z} \frac{(z-y)^{\alpha}}{z} f(y) d y$,

where $z$ is the poverty line and $a$ is the degree of aversion to poverty.

The poverty headcount index, when the degree of aversion to poverty is given as $\alpha=0$, gives us the number of households below the poverty line divided by the total households in the group. This shows the prevalence of poverty but does not give us an indication of the degree of poverty. Poverty depth informs us on the mean shortfall of the income of the poor below the poverty line. In this case, $\alpha=1$, and we can tell the level of income transfer needed to bring all poor households to the poverty line. Finally, we calculate an index for the severity of poverty, which considers the inequality among households that are poor. In this case, with $\alpha=2$, more importance is accorded to the shortfalls of the poorest households. The weight assigned to each household is equal to how far it is from the poverty line (see Ravallion, 1994).

\subsection{Data and calibration}

The most convenient way of working with a model such as the above, is by using a SAM. A SAM for 1995 was constructed and used (Chitiga et al, 2000). Most data for this is published by the CSO and other organisations. The most relevant publications used were National Accounts (CSO, 2000), the Quarterly Digest of Statistics (CSO, 2000), the Income Consumption and Expenditure Surveys (ICES) Report for 1995/96 (CSO, 1999), the SAM for Zimbabwe for 1991 (Thomas \& Bautista, 1999) and agricultural information publications. The year 1995 was chosen as the base year for two main reasons. It occurs within a period in the nineties of relative stability before the onset of financial instability and the land reform policies from the end of 1997 onwards. It is unlikely that any of the years after the onset of these catastrophic events to the present will constitute a stable benchmark or equilibrium underlying CGE analysis. It also occurs in the year in which the survey used for the paper was carried out. As is usual for CGE models, elasticities used to calibrate the model to the benchmark data are taken from the literature. Table A1 in the Appendix documents the elasticities and other benchmark data used in the simulations.

The survey data is carefully grouped into the respective household categories and income sources represented in the SAM. Thus each group represented in the SAM has a corresponding matrix of households in the 1995 Poverty Assessment Survey Study (PASS) data set. The percentage changes in representative household incomes resulting from simulation change are then mapped onto the individual households and poverty measures are estimated for each group.

\section{4 \\ Results}

In this experiment, we simulate an across-theboard removal of tariffs. As is to be expected, all import prices fall after the removal of this trade barrier, as shown in Table 2. Food Manufacturing sees a substantial fall (7.7 per 
cent) in relative prices of imports. The import price of the sector Other Manufacturing and Mining also falls comparatively more (7.56 per cent). Private Services have the least fall in relative prices, as they do not import much.

\section{Table 2}

Complete removal of tariffs simulation results (Prices)

\begin{tabular}{|c|c|c|c|}
\hline Variable & Sector & Level & Variation (\%) \\
\hline \multirow{2}{*}{$\begin{array}{l}\text { EXRXP } \\
\text { (Exchange rate ) }\end{array}$} & & 1 & 4.22 \\
\hline & & & \\
\hline \multirow{6}{*}{$\begin{array}{l}\text { PMXP } \\
\text { (Price of imports) }\end{array}$} & FA & 1 & -4.56 \\
\hline & $\mathrm{OA}$ & 1 & -6.06 \\
\hline & FM & 1 & -7.72 \\
\hline & AIM & 1 & -3.22 \\
\hline & OMM & 1 & -7.56 \\
\hline & PRS & 1 & -1.70 \\
\hline \multirow{8}{*}{$\begin{array}{l}\text { PQXP } \\
\text { (Price of composite goods) }\end{array}$} & FA & 1 & 0.16 \\
\hline & $\mathrm{OA}$ & 1 & 1.38 \\
\hline & FM & 1 & -1.09 \\
\hline & AIM & 1 & -1.86 \\
\hline & OMM & 1 & -5.17 \\
\hline & $\mathrm{CON}$ & 1 & -0.75 \\
\hline & PUS & 1 & 1.99 \\
\hline & PRS & 1 & 0.51 \\
\hline \multirow{2}{*}{$\begin{array}{l}\text { CPIXP } \\
\text { (Consumer price index ) }\end{array}$} & & 1 & -2.01 \\
\hline & & & \\
\hline \multirow{8}{*}{$\begin{array}{l}\text { PVAXP } \\
\text { (Value added price ) }\end{array}$} & FA & 1 & 3.92 \\
\hline & $\mathrm{OA}$ & 1 & 6.73 \\
\hline & FM & 1 & 2.51 \\
\hline & AIM & 1 & -0.32 \\
\hline & OMM & 1 & 2.48 \\
\hline & $\mathrm{CON}$ & 1 & 3.08 \\
\hline & PUS & 1 & 3.46 \\
\hline & PRS & 1 & 3.31 \\
\hline
\end{tabular}

Note: The definitions of the names of the variables in Tables 2 to 4, which are not defined there, are given in the Appendix.

These changes in turn have an impact on the amounts of imports into the country. The lower import prices result in agents substituting domestic goods with imported goods. The specific CES elasticities for each sector determine the amount of substitution that is possible between imports and domestically produced goods. All sectors witness an increase in imports. The non-food agriculture sector shows the largest increase in imports of about 
26 per cent, followed by food agriculture commodities (16.23 per cent) as shown in Table 3 below. The smallest gain is recorded in the private services sector for the reasons explained above. This increase in imports results in an increase in the quantity of the composite good supplied in the economy, thereby countering the negative domestic reductions in quantity supplied.

Relative prices of exports increase for all sectors. This directly benefits export competitiveness as seen in the increase of exports from all sectors, with the other manufacturing and mining sector gaining the most (9.38 per cent), as shown in Table 3 . However, this is not enough to offset the negative effect on sectoral output. These sectors have an initially high quantity of exports as well. The quantity of domestic sales falls the most in the sectors that have larger increases in exports, that is, manufacturing sectors. Agricultural sectors benefit the most in terms of increased domestic sales. Overall, domestic activity falls only in manufacturing sectors but increases in all the other sectors. Thus, the policy of removing tariffs in all sectors has not led to a complete slowdown in domestic activity in all sectors. Non-manufacturing sectors benefit from this policy. With such a picture, we cannot say, $a$ priori, whether there will be reduced or increased income in the economy overall. We have therefore analysed the sectoral impacts on factors of production.

\section{Table 3}

Complete removal of tariffs simulation results (Output)

\begin{tabular}{|c|c|c|c|}
\hline Variable & Household/sector & Level (000) & Variation (\%) \\
\hline \multirow{5}{*}{$\begin{array}{l}\text { EHXP } \\
\text { (Household consumption expenditure) }\end{array}$} & HCR & 4.14 & -0.10 \\
\hline & HLILS & 0.17 & 2.77 \\
\hline & HHLS & 14.56 & -1.70 \\
\hline & HLU & 4.17 & 0.15 \\
\hline & $\mathrm{HHU}$ & 17.17 & -1.18 \\
\hline \multirow{8}{*}{$\begin{array}{l}\text { QAXP } \\
\text { (Level of domestic activity) }\end{array}$} & FA & 6.91 & 2.26 \\
\hline & $\mathrm{OA}$ & 8.92 & 1.79 \\
\hline & $\mathrm{FM}$ & 8.52 & -0.18 \\
\hline & AIM & 0.97 & -1.91 \\
\hline & OMM & 28.78 & -0.25 \\
\hline & $\mathrm{CON}$ & 5.32 & 0.11 \\
\hline & PUS & 10.98 & 0.17 \\
\hline & PRS & 42.35 & 0.64 \\
\hline \multirow{8}{*}{$\begin{array}{l}\text { QDXP } \\
\text { (Quantity of domestic sales) }\end{array}$} & FA & 4.09 & 0.22 \\
\hline & $\mathrm{OA}$ & 1.87 & -0.65 \\
\hline & $\mathrm{FM}$ & 7.93 & -0.70 \\
\hline & $\mathrm{AIM}$ & 0.93 & -2.11 \\
\hline & OMM & 21.03 & -3.91 \\
\hline & $\mathrm{CON}$ & 5.32 & 0.11 \\
\hline & PUS & 10.98 & 0.17 \\
\hline & PRS & 37.02 & 0.41 \\
\hline
\end{tabular}




\begin{tabular}{|l|c|c|c|}
\hline \multirow{4}{*}{$\begin{array}{l}\text { QEXP } \\
\text { (Quantity of exports) }\end{array}$} & FA & 2.82 & 5.16 \\
\cline { 2 - 4 } & OA & 7.04 & 2.44 \\
\cline { 2 - 4 } & FM & 0.60 & 6.56 \\
\cline { 2 - 4 } & AIM & 0.03 & 4.16 \\
\cline { 2 - 4 } & OMM & 7.75 & 9.38 \\
\cline { 2 - 4 } & PRS & 5.33 & 2.20 \\
\hline QMXP & FA & 0.10 & 16.23 \\
\cline { 2 - 4 } & OA & 0.07 & 26.03 \\
\cline { 2 - 4 } & FM & 1.92 & 10.64 \\
\cline { 2 - 4 } & AIM & 0.69 & 5.35 \\
\cline { 2 - 4 } & OMM & 24.03 & 4.38 \\
\cline { 2 - 4 } & PRS & 1.50 & 1.59 \\
\hline
\end{tabular}

Labour is one of the main resources that the poor possess, and thus determines their status after a shock. On the labour market, only skilled labour has a flexible wage and it is assumed to be in full employment. There is a relocation of this labour type from all manufacturing sectors to the agriculture and the services sectors as these sectors expand. Overall, the relative price of this factor increases due to the demand in agriculture and services. This implies a relative fall in the price of unskilled labour which increases demand for this factor. All sectors increase their demand for unskilled and informal labour, especially in the agricultural sectors. Unskilled labourers benefit from the increased demand due to the fixed wage. As is to be expected, the increase in domestic activity in agriculture raises the rent for land and capital. Although capital prices increase in all sectors, agriculture posts the highest, as this sector gets the most benefit from this policy. This suggests a larger capital gain for farmers compared to the urban capital income earners.

Table 4

Complete removal of tariffs simulation results (Incomes)

\begin{tabular}{|c|c|c|c|}
\hline Variable & Household/sector & Level $(000)$ & Variation $(\%)$ \\
\hline YIXP & HCR & 4.33 & 2.87 \\
\hline \multirow[t]{5}{*}{ (Income of (dom non-gov) institutions) } & HLILS & 0.20 & 6.40 \\
\hline & HHLS & 18.59 & 1.67 \\
\hline & HLU & 5.28 & 3.29 \\
\hline & $\mathrm{HHU}$ & 23.89 & 2.36 \\
\hline & ENT & 24.95 & 2.59 \\
\hline \multirow{9}{*}{$\begin{array}{l}\text { YFXP } \\
\text { (Factor income) }\end{array}$} & LUSKAG & 0.20 & 6.40 \\
\hline & FLUSK & 1.43 & 3.67 \\
\hline & ILUSK & 4.50 & 4.50 \\
\hline & LSK & 18.80 & 3.67 \\
\hline & SHKAAG & 0.60 & 7.37 \\
\hline & LSKAAG & 3.04 & 8.60 \\
\hline & KANA & 24.89 & 3.07 \\
\hline & SHLAND & 0.34 & 8.03 \\
\hline & LLAND & 0.81 & 8.58 \\
\hline YGXP (Government income) & & 15.25 & -18.48 \\
\hline
\end{tabular}


Factor incomes increase for all types of factors, with agricultural capital and land gaining the most, as shown in Table 4. Skilled labour benefits less, and unskilled labour relatively more, in terms of labour income due to the increase in hiring. This is especially pronounced in the agricultural sectors. The macro-economic results compare well to those obtained by Bautista et al. (1998). All domestic nongovernmental institutions see an increase in income. In terms of percentage changes, the income of large-scale farm workers benefits the most, followed by low-income urban households. However, government income falls significantly, by 18.48 per cent, as tariff revenue falls, leading to reduced government activity. The changes that occur in the households at the macro-level are transferred to each household in each group to access the group's change in poverty.

\subsection{Impact on poverty}

Figure 3 below shows the changes in poverty that occur for each of the groups. The density curves trace the intra-household distribution of income in a group and the vertical lines are the poverty lines. After this policy experiment, the poverty line of ZD $\$ 2,123.46$ (PASS, 1996) shifts to the left. The more the line is to the right, the higher the poverty in that particular group. Thus fewer people, at the original incomes, are below the poverty line. Income inequality, at least at certain income levels, is increasing in the poorer groups and remains relatively unchanged in the richer household groups, that is, the large-scale farmers and the urban rich households.

Depending on what happens to the incomes and the poverty line, we can tell whether more or fewer people are below the poverty line after the simulation. In the results, we see that all incomes go up, and the curves show that the number of households with low incomes is either reduced or remains the same after the simulation at different income levels for most groups. In the case of communal and resettled farmers, however, we see that the frequency of people with the lowest incomes increases after the simulation compared to before. The pictures below also show which groups contain larger numbers of households living below the poverty line. Large-scale commercial farmers and urban rich households have the smallest numbers of households living below the poverty line, while in the other groups, the majority of the households are poor.

The new poverty line falls mainly because all incomes increase. This counters the increase in some prices, such as food. Fewer people in each group are below the poverty line compared to the period before the simulation. This means that the increase in income that mostly occurs after trade liberalisation has allowed some households to move out of poverty. 
Figure 3

Density curves and poverty lines for income before and after a simulation

Communal income

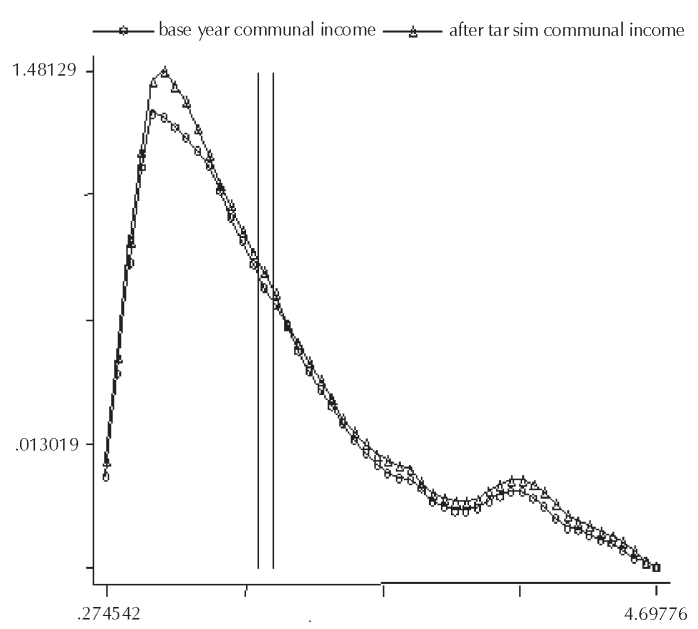

LSC Farmers

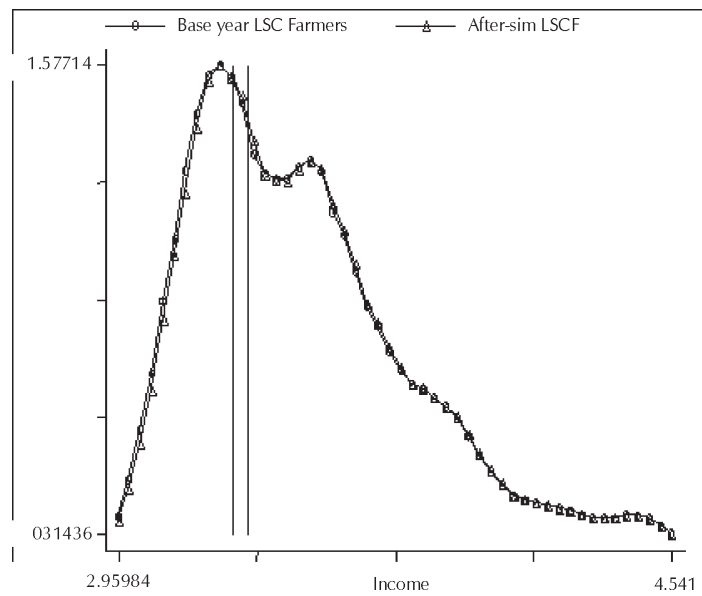

Urban rich

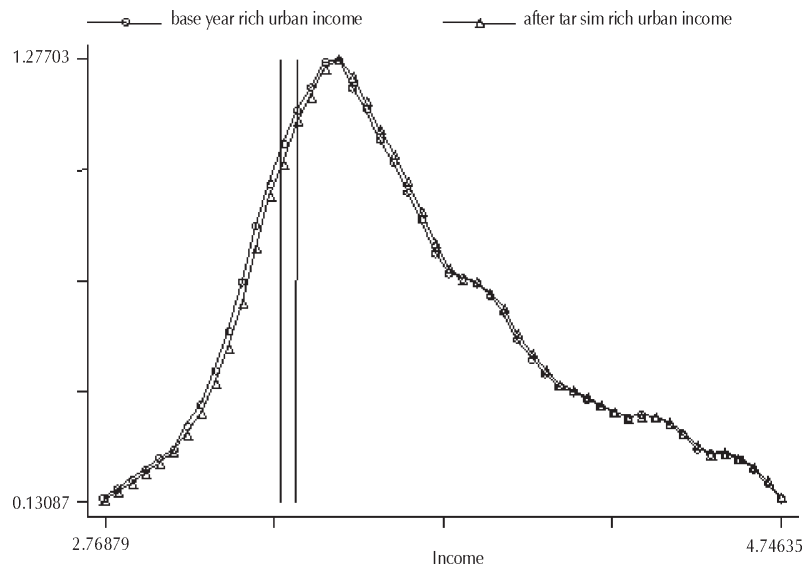

LSCF workers income

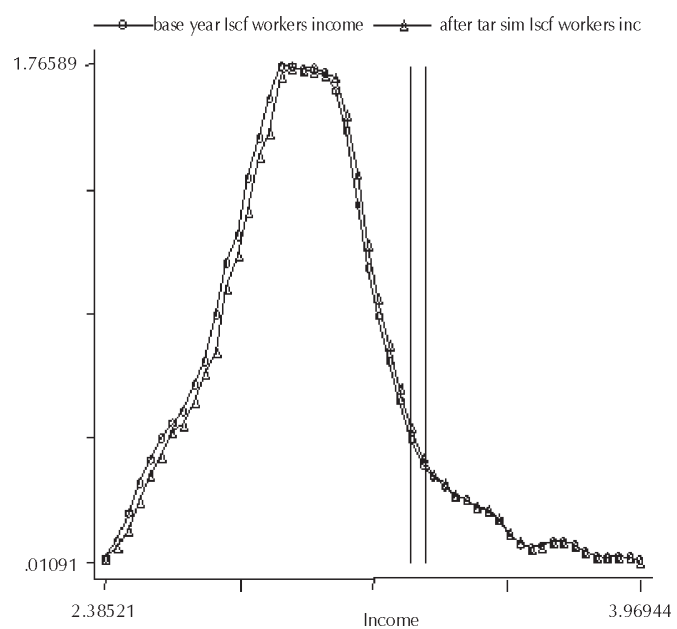

Urban poor

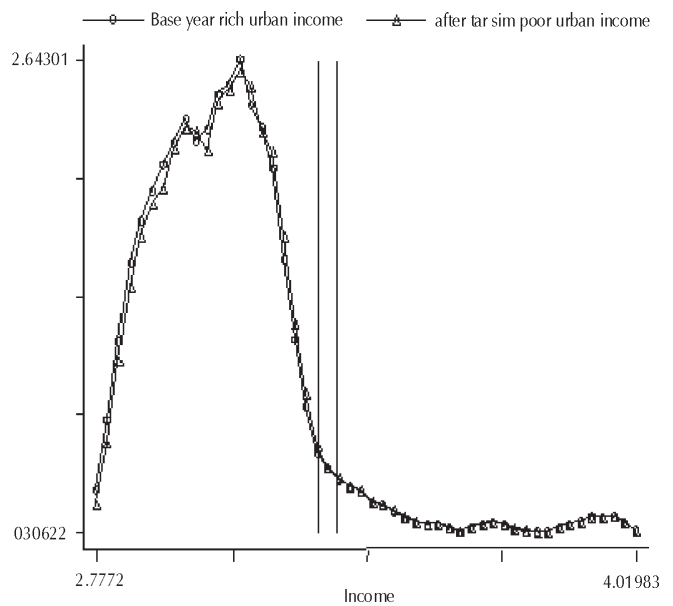


It can be seen from Table 5 that poverty is falling for all groups for all poverty measures and in all categories, but more so for the richer groups (LSC Farmers and the urban rich). We observe then that in line with the popular cliché, those groups already rich get richer relative to those that are poorer. There is increased income inequality even though overall poverty is falling. However, those who spend relatively higher proportions of income on food, the poorer groups, benefit relatively less from the consumption side developments. These are important results given that the usual assumption in Zimbabwe was that trade liberalisation led to increased poverty. Thus in all policy packages, it is worth looking at the impact of individual components in order to make informed decisions about poverty.

Table 5

Changes in poverty

\begin{tabular}{|l|c|}
\hline Changes in Poverty & \% Change \\
\hline Poverty headcount $\left(\mathrm{P}_{0}\right)$ & \\
\hline Communal and resettled farmers & -0.21 \\
\hline LSCF workers & -0.50 \\
\hline LSCF farmers and managers & -0.66 \\
\hline Urban poor & -0.36 \\
\hline Urban rich & -0.56 \\
\hline Poverty Depth $\left(\mathrm{P}_{1}\right)$ & \\
\hline Communal and resettled farmers & -0.16 \\
\hline LSCF workers & -0.23 \\
\hline LSCF farmers and managers & -0.41 \\
\hline Urban poor & -0.31 \\
\hline Urban rich & -0.31 \\
\hline Poverty Severity $\left(\mathrm{P}_{2}\right)$ & -0.18 \\
\hline Communal and resettled farmers & -0.10 \\
\hline LSCF workers & -0.13 \\
\hline LSCF farmers and managers & -0.38 \\
\hline Urban poor & -0.25 \\
\hline Urban rich & \\
\hline
\end{tabular}

5

\section{Summary and conclusion}

This paper uses an overall framework that generates poverty measures from survey data based on the full household survey, without requiring any assumption about the $\mathrm{XXX}$ within distribution of households. We believe this framework captures important channels through which trade liberalisation affected household incomes. Compared to standard CGE analysis, the framework developed in this paper allows us to decompose the effects of trade liberalisation on poverty. Such a methodology can bring much-needed insights into other policy impacts on poverty, and could be used for other countries battling with the balance between policy and poverty. Our results suggest that poverty is falling for all groups for all our poverty measures $\left(\mathrm{P}_{0}, \mathrm{P}_{1}\right.$ and $\left.\mathrm{P}_{2}\right)$, and in all categories, but more so for the less poor groups. The results show that those groups already rich get richer relative to those that are poorer. Despite the fall in overall poverty, there is increased income inequality because the richer groups benefit more than the poorer groups in poverty reduction. Furthermore, those who spend relatively higher proportions of income on food benefit relatively less as consumers.

The analysis in this paper is largely based on a 'viable' Zimbabwe of the late 1990s and for reasons mentioned above, no attempt has been made to benchmark the model to years after 2000. It is important to highlight that the structure of the economy in present-day, postland redistribution Zimbabwe is still evolving. The conclusions of this paper would thus need to be reviewed in the light of the final economic structure of the country if they were to be applied. However, if in the long-term the economy settles to a structure that does not differ much in terms of performance to the economy of the 1990s, then not much adjustment to the current model would be required. 


\section{Endnote}

The research was funded by a research grant from the African Economic Research Consortium, and this is gratefully acknowledged. Comments from the AERC technical committee members of group A are gratefully acknowledged. We thank Professor Arne Bigsten for assistance with software. We also thank Hans Löfgren, James Thurlow and several colleagues for answering many questions. Suggestions from anonymous referees are also acknowledged. Any errors remain our own.

\section{References}

1 ADELMAN, I. \& ROBINSON, S. (1979) "Income distribution policy: a computable general equilibrium model of South Korea", in Adelman, I, The Selected Essays of Irma Adelman (vol 1) Dynamics and income distribution. Economists of the Twentieth Century Series. Aldershot, U.K.: 256-89.

2 ARMingTON, P. (1969) "A theory of demand for products distinguished by place of production", IMF Staff Papers, 16(1).

3 BAUTISTA, R., LOFGREN, H. \& THOMAS, M. (1998) "Does trade liberalisation enhance income growth and equity in Zimbabwe? The Role of complementary policies", TMD Discussion Paper No 32 Washington DC: IFPRI.

4 BOCCANFUSO, D.; DECALUWE, B. \& SAVARD, L. (2002) "Poverty, income distribution and CGE modeling: Does the functional form of distribution matter?" CREFA working paper.

5 CHITIGA-MABUGU, M. (2001) "Income distribution effects of trade liberalisation: A CGE Analysis" in C Mumbengegwi (ed.) Macroeconomic and Structural Adjustment Policies in Zimbabwe, Palgrave: Houndsmill.

6 CHITIGA, M.; DAVIES, R. \& MABUGU, R. (2000) "A 1995 Social accounting matrix (SAM) for Zimbabwe", A dataset submitted to SIDAZimbabwe office, Unpublished.

7 DAVIES, R.; RATTS, J. \& TORVIK, R. (1994) "The macroeconomics of Zimbabwe in the 1980's: A CGE-model analysis", Journal of African Economies, 3: 153-98.

8 DECALUWÉ, B.; DUMONT, J.C. \& SAVARD, L. (1999) "Measuring poverty and inequality in a computable general equilibrium model", Working Paper 99-20 CREFA, University of Laval.

9 ELBADAWI, I.A. \& SCHMIDT-HEBBEL, K. (1991) "Macroeconomic structure and policy in Zimbabwe", Working Paper 771, Country Economics Department, The World Bank.

10 FOSTER, J.; GREER, J. \& THORBECKE, E. (1984) "A class of decomposable poverty measures" Econometrica, 52(3): 761-6.

11 GOVERNMENT OF ZIMBABWE (1996) 1995 Poverty Assessment Study Survey (PASS) Main Report, (MPSLSW) Harare.

12 GOVERNMENT OF ZIMBABWE (CSO) (1995) "Inequality among households in Zimbabwe: An assessment using the 1990/ 91income consumption and expenditure survey": Harare.

13 GOVERNMENT OF ZIMBABWE (CSO) (1998) "Poverty in Zimbabwe": Harare.

14 GOVERNMENT OF ZIMBABWE (CSO) (2002) National Accounts 1985-2000: Harare.

15 LÖFGREN, H.; LEE HARRIS, R. \& ROBINSON, S. (2001) "A standard computable general equilibrium (CGE) model in GAMS" TMD discussion paper no. 75, Trade and Macroeconomics Division, IFPRI, Washington, D.C. U.S.A. available at http://www.cgiar.org/ ifpri/divs/tmd/dp.htm

16 MABUGU, R. (2001) "Short run effects of tariff reform in Zimbabwe: Applied general equilibrium analysis", Journal of African Economies, 10(2).

17 MEHLUM, H. (1999) "The political economy of failing reform", Ph.D. dissertation, University of Oslo, Norway.

18 ORGANISATION FOR ECONOMIC COOPERATION AND DEVELOPMENT (OECD) (2004) "The African economic outlook report 2002/03”, available at: http://www.oecd.org/ document/

19 PAKKIRI, L. \&. MOYO. N.P. (1986) "Foreign exchange policies: The case of Zimbabwe", IDRC Workshop on Economic Structure and Macroeconomic Management, Harare.

20 RESERVE BANK OF ZIMBABWE (1997) Annual Report, Harare.

21 RESERVE BANK OF ZIMBABWE (1999) Weekly Economic Highlights, 4 June.

22 RESERVE BANK OF ZIMBABWE (2002a) Monthly Statistical Bulletin, January.

23 RESERVE BANK OF ZIMBABWE (2002b) Weekly Economic Highlights, January.

24 SAVARD, L. (2003) "Poverty and inequality analysis within a CGE Framework: A comparative analysis of the representative agent 
and micro-simulation approaches", Working Paper CIRPEE, Université Laval No 04-12. (forthcoming in Development Policy Review)

25 STIFEL, D, \& THORBECKE, E. (2002) $A$ Dual-Dual Model of an Archetype African
Economy: Trade Reform, Migration and Poverty. Draft, Cornell University.

26 WORLD BANK (1998) World Development Report, Washington DC.

\section{Appendix: Elasticities and other benchmark data}

\section{Table A1}

Model elasticities and trade shares

\begin{tabular}{|l|c|c|c|c|c|c|}
\hline Sector & \multicolumn{3}{|c|}{ Elasticity } & \multicolumn{3}{c|}{ Sectoral share } \\
\hline & $T m$ & $\varepsilon_{\mathrm{m}}$ & $\varepsilon_{\mathrm{x}}$ & $\mathrm{M}_{\mathrm{i}} / \mathrm{M}$ & $\mathrm{EX}_{\mathrm{i}} / \mathrm{EX}$ & $\mathrm{VA}_{\mathrm{i}} / \mathrm{VA}$ \\
\hline FA & 0.092 & 3.000 & 1.250 & 0.3 & 12 & 6.5 \\
\hline OA & 0.109 & 3.000 & 1.250 & 0.3 & 29.9 & 8.7 \\
\hline FM & 0.129 & 1.250 & 2.000 & 6.7 & 2.5 & 7.8 \\
\hline OMM & 0.127 & 1.500 & 2.000 & 87 & 33 & 23.9 \\
\hline PRS & 0.060 & 0.500 & 0.500 & 5.6 & 22.6 & 35.940 \\
\hline CON & & & & & & 3.090 \\
\hline PUS & & & & & & 14.070 \\
\hline
\end{tabular}

\section{Definitions not included in the text}

tm Initial tariff rates

$\varepsilon_{\mathrm{m}} \quad$ Armington elasticities

$\varepsilon_{\mathrm{X}} \quad$ CET elasiticities

$\mathrm{M}_{i} / \mathrm{M} \quad$ Sectoral import shares

EX $_{\mathrm{i}} / \mathrm{EX} \quad$ Sectoral export shares

$\mathrm{VA}_{\mathrm{i}} / \mathrm{Va} \quad$ Sectoral value-added share

LUSKAG Unskilled agriculture labour

FLUSK Formal unskilled labour

ILUSK Informal unskilled labour

LSK Skilled labour

SHKAAG Smallholder agriculture capital

LSKAAG Large-scale agriculture capital

KANA Non-agriculture capital

SHLAND Smallholder land

LLAND Large-scale agriculture land 